\title{
2 Universalism versus Particularism
}

\subsection{Choosing between Torture and Terrorism: Mr. Chahal vs. the U.K. Population}

IN 1996, the European Court of Human Rights had to decide whether the United Kingdom would violate the ECHR by executing an order for deportation of Mr. Chahal to India. Mr. Chahal was a Sikh separatist, and the U.K. Home Secretary motivated the deportation decision by adducing that his 'continued presence in the United Kingdom was unconducive to the public good for reasons of national security and other reasons of a political nature, namely the international fight against terrorism'. ${ }^{180} \mathrm{Mr}$. Chahal's application for asylum was turned down in several instances and the deportation order was upheld after an advisory panel had considered the aspects of national security involved in the case. Mr. Chahal's solicitors then turned to the European Commission for Human Rights, which referred the case to the Court. The Court found by twelve votes to seven that the implementation of the deportation decision would infringe upon the prohibition of torture, inhuman or degrading treatment spelt out in Article 3 ECHR. The Court majority considered this prohibition

180 ECtHR, Chabal vs. the U.K., 15 November 1996, Reports 1996-V [henceforth Chahal], para. 25. The Chahal case is further analysed in chapter 12.2.2.3 below.

(C) GREGOR NOLL, 2000 | DOI:10.1163/9789004461543_003

This is an open access chapter distributed under the terms of the CC BY-NC 4.0 license. 


\section{CHAPTER 2}

to be of an absolute character, making aspects of national security legally irrelevant to the case. ${ }^{181}$ The Court minority, however, held that the United Kingdom could legitimately weigh the interest of national security against the individual's interest not to be ill-treated. ${ }^{182}$

The Chabal case represents a formidable extrapolation of the protection dilemma. Should Mr. Chahal be protected from ill-treatment in India at the price of exposing the population of the U.K. to his terrorist potential? ${ }^{183}$ Granting for the moment that Mr. Chahal's continued presence indeed posed a danger to the population of the United Kingdom, and that he was indeed threatened by mistreatment in India, there is obviously more than one arguable answer to the question of principlenamely, whose interests shall be sacrificed. Put differently, the Court had to make a choice between two risks: torture and terrorism.

Far from all cases turning on extraterritorial protection contain such a dramatic opposition of interests as Chahal. Even in less poignant claims, however, an identically structured opposition between individual and host community can be made out. What are the ideological underpinnings of that structure?

Migration and asylum law are situated in the conflict zone between universalism and particularism, leaving lawyers with a choice between two foundational paradigms-one striving for the global realisation of human rights and another giving preference to the interests of a certain state population. The Chabal case is a very accurate reflection of this choice. The Court was offered a particularist reading by the U.K. government, and Mr. Chahal's counsel seconded it with a universalist reading. The Court minority embraced the former, while the Court majority opted for the latter. Leaving aside the determinacy won in casu Chabal, the tension between these foundational paradigms persists and merits further exploration.

${ }^{181}$ Chabal, paras 79-82. See chapter 11 for a discussion of the 'absolute' character of the right enshrined in Art. 3 ECHR.

${ }^{182}$ Chabal vs. the U.K., Joint Partly Dissenting Opinon of Judges Gölcüklü, Matscher, Freeland, Baka, Totchev, Bonnici and Levits, para. 1.

${ }^{183}$ It is not for this author to judge whether Mr. Chahal's qualification as a threat to national security was an adequate reflection of facts. At any rate, it does not affect the abstract tension between the interest of the individual protection seeker and the potential host community. 


\subsection{Universalism}

To start with, refugee law is about the inclusion of an individual in a collective protection system. A protection seeker no longer enjoys the protection of her ${ }^{184}$ home community and is thus compelled to seek such protection elsewhere. The claim to inclusion in a host community is a mere consequence of exclusion by the home community. It is premised on the idea that each individual is part of a global community, which has to secure a minimum level of protection, where the local community-i.e. the nation state-fails. This is a universalist reading, which sets the existential interest of the individual prior to that of a potential host community. The level of protection to be granted is specified in international human rights instruments, and states are not only singularly, but also collectively, the guarantors of their implementation. Simplifying, one could claim that, where one state fails, another one picks up its protection obligations. This conception seems to have inspired the Court majority in Chabal.

Historically, legal universalism dates back at least to the days of the Roman Empire, where a need was felt to overarch the legal plurality of occupied territories with a single jus commune. To wit, this form of universalism drew on factual inequality. It was not applicable to the legal relationships between Romans (which were subject to jus civile), but solely governed those between Romans and Non-Romans, or those amongst Non-Romans. To find a common denominator for the multitude of societies forming part of the Roman Empire, law was compelled to assume a high level of abstraction. Its underlying assumption was the 'sovereignty of the unqualified individual'. ${ }^{185}$ By this abstraction, Roman

${ }^{184}$ In this work 'she' and 'her' refers to both sexes. Due to the lack of sufficiently detailed data, it is difficult to generalise about the percentage of female protection seekers and refugees. Data from refugee camps situated in the developing world suggest that 50.9 percent of the refugee population is female. UNHCR, Refugees and Others of Concern to UNHCR, 1998 Statistical Overview (1999, UNHCR, Geneva), pp. 32 and 36. Moreover, in 49 countries for which statistics were available, recognition rates for female protection seekers were significantly higher than for male protection seekers (47.6 percent opposed to 14.8 percent). Against this background, it seems appropriate to reflect the probability of a female majority among protection seekers and recognised refugees by using the female pronoun. For the sake of simplicity, this order is retained with regard to all groups of persons alluded to in the present work. By consequence, the personal pronoun used for unspecified police officers, judges or human smugglers is also 'she'.

185 S. Tönnies, Der Westliche Universalismus (1995, Westdeutscher Verlag, Opladen), p. 70. 


\section{CHAPTER 2}

law gave universalism its decisive conceptual tool: the idea of equality. Later, this idea was combined with the concept of human rights, which gave universalism an enhanced potential for explaining and influencing societal relations. This combination is a distinct feature of enlightenment thinking at large and can be traced in the constitutional documents of the bourgeois revolutions.

Therefore, it is of little surprise to find a manifestation of the universalist foundations of refugee law with the German enlightenment philosopher Immanuel Kant. In his treatise 'On Eternal Peace', he sketched out a pacified world community, featuring republican constitutions within states, a public international law based upon legal federalism among states and, finally, an individual right to hospitality for any 'world citizen'. ${ }^{186}$

Kant formulates the latter right bluntly in the third operative article of his treatise:

Das Weltbürgerrecht soll auf Bedingungen der allgemeinen Hospitalität eingeschränkt sein. ${ }^{187}$

The individual right to hospitality is based on two premises. As the Earth is formed as a globe, its inhabitants cannot disperse infinitely, but are compelled to meet sooner or later. Originally, nobody has a greater right to be at a certain place than anybody else. From these premises, Kant draws the weak conclusion ${ }^{188}$ that each individual has a right of visit (Besuchsrecht), implying that she must not be treated in a hostile manner barely due to her arrival on the soil of another individual. The original inhabitant may, however, expel her, provided this can take place without exposing her to peril. ${ }^{189}$ These cautious formulations must be seen against

With the 'unqualified individual', Tönnies intends a person perceived without regard to her membership in a group and independent from her position in this group.

${ }^{186}$ I. Kant, Zum ewigen Frieden: ein philosophischer Entwurf, 1984 ed. (Theodor Valentiner and Rudolf Malter eds), (1795, Reclam, Stuttgart).

${ }^{187}$ Kant, 1795, p. 21. ['Cosmopolitan law shall be restricted to conditions of general hospitality.' Translation by W. Schwarz, Principles of Laweful Poltics. Immanuel Kant's Draft Toward Eternal Peace (1988, Scientia Verlag, Aalen), p. 83].

${ }^{188}$ R. Bauböck, 'Ethical Problems of Immigration Control and Citizenship', in R. Cohen (ed.), The Cambridge Survey of World Migration (1995, Cambridge University Press, Cambridge), p. 162.

${ }^{189}$ Kant, 1795, p. 21. 
the background of European colonialism. Kant was careful to restrict the world citizen right in such a manner that it may not be abused for the domination or exploitation of host societies. ${ }^{190}$

This world citizen's right outlines the balance to be struck in positive law in a much later stage. The host society has a right to control the composition of its population, but this right finds its limits where the security of the expellee would be threatened. The latter limitation is indeed the nucleus of a norm that is regarded as the cornerstone of contemporary refugee law, namely the prohibition of refoulement, expressly codified in Article 33 of the 1951 Refugee Convention ${ }^{191}$ and Article $3 \mathrm{CAT}^{192}$. What remains extremely intriguing, though, is the element of free movement inherent in the Kantian right of visit: the world citizen is entitled to enjoy social contacts abroad. The ever stricter limitation of migration in our times stands out in stark contrast to this model liberty. At present, strict visa requirements prevent movements to other countries, where the individual could have invoked the modern counterpart to the protective element inherent in Kant's right of visit, namely the prohibition of refoulement.

Kant justifies the necessity of the world citizen's right with the fact that the effects of legal violations can no longer be limited to one part of the world:

Da es nun mit der unter den Völkern der Erde einmal durchgängig überhand genommenen (engeren oder weiteren) Gemeinschaft so weit gekommen ist, dass die Rechtsverletzung an einem Platz der Erde an allen gefühlt wird: so ist die Idee eines Weltbürgerrechts keine phantastische und überspannte Vorstellungsart des Rechts, sondern einen notwendige Ergänzung des ungeschriebenen Kodex sowohl des Staats- als Völkerrechts zum öffentlichen Menschenrechte überhaupt und so zum ewigen Frieden, zu dem man sich in der kontinuierlichen Annäherung zu befinden nur unter dieser Bedingung schmeicheln darf. ${ }^{193}$

${ }^{190}$ Höffe points out that the world citizen right has two countercurrent tasks, namely to protect the rights of arriving persons as well as of native populations. O. Höffe, Vernunft und Recht (1996, Suhrkamp, Frankfurt), pp. 127-8.

${ }^{191}$ See chapter 9.1.2.1 below.

192 See chapter 9.1.2.2 below.

${ }^{193}$ Kant, 1795 , p. 24. ['As the generally prevailing (more or less close) community among the peoples of the earth has now undeniably reached the point that the violation of right in one place of the earth is felt in all places, the idea of a cosmopolitan law is not a fantastic 


\section{CHAPTER 2}

Traditionally, this position has been interpreted as Kant's attempt to counter the atrocities of colonialism. Simultaneously, this passage is an early formulation of the responsibility incumbent on all states to secure human rights on a global level. The causality is clear: approximating eternal peace presupposes complementing constitutional law and public international law with the granting of a hospitality right to every world citizen. By granting an individual interest the status of a carefully delimited right, Kant promotes the public interest of peace. Setting the individual interest prior, the public interest is nevertheless consumed by it. In its Kantian form, universalism does not offer itself as a one-sided perception of the whole, but takes on the cloak of a ready-made balance between the universal and the particular. Contemporary universalists reproduce this technique when defending their position. ${ }^{194}$

In sum, the universalist idea is that equality overrides the closure of nation states. This idea finds many expressions in the various discourses relevant for the understanding of extraterritorial protection. In political theory, Rawls has asserted the dominance of the fundamental right over the distribution of material goods ${ }^{195}$, which strikes against a limitation to the distribution of wealth solely within nation states, regardless of the position of outsiders. Soysal argues migrant rights flow from 'personhood': they are implemented by states, but draw legitimacy from a supranational discourse on universal human rights. ${ }^{196}$ We shall return to a detailed presentation of certain contemporary universalist positions later in this chapter.

and extravagant conception of right but a necessary complement of the unwritten code of both the law of the state and the law of nations for an encompassing public law and right of men and thus for eternal peace, which to approach continually one can flatter oneself only on this condition.' Translation by Schwarz, 1988, p. 87.]

${ }^{194}$ For a contemporary attempt to strike a balance predicated on Kant's treatise, see S. Chauvier, Du Droit d'Être Étranger. Essai sur le concept kantien d'un droit cosmopolitique (1996, L'Harmattan, Paris).

195 J. Rawls, A Theory of Justice (1971, Harvard University Press, Cambridge, Mass,), pp. 62, 274-83.

196 Y. Soysal, Limits of Citizenship. Migrants and Postnational Membership in Europe (1994, University of Chicago Press, Chicago), ch. 8. 


\subsection{Particularism}

A particularist would explain things differently. In its essence, a claim for protection is prima facie a claim for resources-be they material, political, social or other. ${ }^{197}$ Obviously, a claim of inclusion juxtaposes the claimant with a bounded host community. And the very idea of a bounded community is to match community tasks with community resources. ${ }^{198}$ Once this match has taken place, bounded communities are eager to avoid additional costs for a variety of reasons. One of these reasons has a bearing on human rights. Collective structures like states are a means to secure a certain standard of protection for citizens. Where protection presupposes the existence of a state, there are good reasons to protect the very existence of that state. Protecting its existence means inter alia restricting the access of new participants, so as not to destabilise the fiscal, social, political and physical resource base it rests upon. ${ }^{199}$ Therefore, for the particularist, the universalist perspective is a dangerous one, which ultimately threatens to deteriorate the aggregate level of protection within a host community. It is precisely along these terms that Her Majesty's government proceeded in Chabal. The Court minority accepted this reasoning as an arguable approach under the ECHR. Ultimately, this community-centered argumentation leads the particularist to invoke an

197 The prima facie-character of this claim is derived from the fact that even temporally and materially minimised forms of integration trigger costs, which will be borne by the host community. However, it must be recalled that protection seeker also contribute to the generation of resources by putting their competence and labour at the disposal of host communities. It is quite another matter that some legislations inhibit them from doing so by denying access to labour markets. At any rate, universalists tend to underscore the contributing potential of migration, while particularists typically stress its consumption of resources. For the usage of economistic metaphors in refugee law discourse, see, e.g., D. A. Martin, 'The Refugee Concept: On Definitions, Politics and the Careful Use of a Scarce Resource', in H. Adelman, Refugee Policy. Canada and the United States (1991, York Lanes Press, North York), referring to asylum as a 'scarce resource'.

198 'Smaller units would be hampered by their limited resource base; wider units, although for the reverse reason, would be unable to generate a distributive consensus.' D. Miller, 'The Ethical Significance of Nationality', 98 Etbics 4 (1988), p. 661.

199 'Freedom, wherever it existed as a tangible reality, has always been spatially limited. This is especially clear for the greatest and most elementary of the negative liberties, the freedom of movement; the borders of national territory or the walls of the city-state comprehended and protected a space in which men could move freely. [...] [E]ven under modern conditions, the elementary coincidence of freedom and limited space remains manifest.' H. Arendt, On Revolution (1963, Faber \& Faber, London, p. 279. 


\section{CHAPTER 2}

existential threat to the state for justifying restrictionist measures against protection seekers. ${ }^{200}$

While the universalist perspective focuses on the existential threat facing the individual, the particularist perspective is eager to avoid existential threats facing communities. The particularist professes one for all, while the universalist endorses all for one. If the universalist orders the world along the concept of equality, the particularist insists on freedomif necessary, a freedom from obligation and responsibility vis-à-vis individuals not part of the particularist community. Indeed, the price and risk of this freedom is the dimension of evil. ${ }^{201}$

This does not necessarily mean that the particularist could not care less about refugees. But according protection seekers a claim to inclusion would be at odds with the present system of bounded communities-i.e. nation states. ${ }^{202}$ Let us illustrate particularist thinking through Michael Walzer, a renowned social scientist and one of the flagship names of communitarianism. Walzer suggests that the individual enjoyment of social goods at large is possible only through the intermediary of a community, which, in turn, presupposes some form of boundary between members and non-members:

The theory of distributive justice begins, then, with an account of membership rights. It must vindicate at one and the same time the (limited) right of closure, without which there could be no communities at all, and the political inclusiveness of the existing communities. For it is only as members somewhere that men and women can hope to share in the other social goods-security, wealth, honor, office and power-that communal life makes possible. $^{203}$

${ }^{200}$ In the debate on the asylum provision of the German Constitution, Doehring has defended a limitative position, drawing on the right of states to protect themselves as part of international law. K. Doehring, 'Asylrecht und Staatsschutz', 26 ZaöRV(1966), p. 53 ff.

201 R. Safranski, Das Böse oder Das Drama der Freiheit (1999, Fischer Taschenbuch Verlag GmbH, Frankfurt am Main), p. 193.

${ }^{202}$ For the issue of migration at large, Bauböck formulates the problem as follows: 'If, prima facie, citizenship is a resource that requires bounded political communities for its generation, how can there be a prima facie case for free access to such communities?' Bauböck, 1995, p. 551.

${ }^{203}$ M. Walzer, Spheres of Justice. A Defense of Pluralism and Equality (1983, Basic Books, New York), p. 63. 
The linkage is clear: equality among members is bought at the price of excluding non-members. ${ }^{204}$ While relationships among members are governed by an overarching standard of justice, the same is not true for the relationship between members and non-members:

The distribution of membership is not pervasively subject to the constraints of justice. [...] At stake here is the shape of the community that acts in the world, exercises sovereignty, and so on. Admission and exclusion are at the core of communal independence. ${ }^{205}$

In reaching this conclusion, Walzer compares states to neighbourhoods and private clubs. This analogy enticed him to the widely quoted statement 'if states were to become large neighbourhoods, it is likely that neighbourhoods will become little states ${ }^{206}$. Now, states' freedom in distributing membership is not unrestricted. Walzer introduces an obligation to provide help to others who are in dire need, even if we have not established bonds with them, under the precondition that such help can be rendered without excessive costs to ourselves. ${ }^{207}$ Consequently, Walzer denies that there is a general obligation to admit refugees, making exceptions for groups whose exodus the host nation caused, or to which it has ethnic or ideological bonds. ${ }^{208} \mathrm{~A}$ number of scholars have taken issue with Walzer's argument; amongst others, Joseph Carens has crafted powerful counter-arguments, to which we shall revert at a later stage. ${ }^{209}$

Generalising beyond Walzer's specific position, we may frame the particularist argument as follows. For particularist systems to survive, it has to be accepted as inevitable that single individuals be put in limbo. Hence, assistance to non-community members is a matter of benevolence or, in Walzer's terms, mutual aid. Where the community is strong, the prospects for benevolence vis-à-vis non-members are good. Therefore, strengthening the state means creating the very preconditions for assisting refugees. Regarded thus, the opposition of universalism and particularism

\footnotetext{
204 We shall revert to this issue in chapter 13.1.3 below.

205 Walzer, 1983, pp. 61-2.

206 Walzer, 1983, p. 38.

207 Walzer, 1983, pp. 33 and 45-6.

208 Walzer, 1983, pp. 48-51.

${ }^{209}$ See chapter 2.6 below.
} 


\section{CHAPTER 2}

is theoretically sublated in the concept of protection. Both paradigms would ultimately aim at successively assisting the largest possible number of individuals in the most efficient way. Both claim to possess the key to securing its most widespread achievement-within and outside host communities. In the particularist paradigm, the price is victimisation the single refugee denied protection for the sake of this noble collective aim. Thus, the collective interest is set prior, and the interests of the individual are consumed by it. This is precisely a reversion of the universalist argument.

On an axiomatic level, universalism assumes that individuals' human rights must not be made conditional upon the existence of intermediary institutions such as states. Being a human is both necessary and sufficient for enjoying human rights. Particularists, on the other hand, set an inextricable linkage between rights and community prior: rights can only be enjoyed through the intermediary of a community, whose members grant them to each other. Thus, being a human is a necessary, but not sufficient, condition for the enjoyment of human rights. These axioms determine the distribution of the burden of proof: universalists claim that particularists need to prove the necessity of restriction, while particularists claim that universalists have to provide arguments for permitting expansion in providing access to protection seekers.

\subsection{Human Rights versus Sovereignty}

Against the background of the Chabal case, we have retraced and extrapolated the divide between a global implementation of human rights and the interests of a certain state as part of a larger conflict between universalism and particularism. Put bluntly, this opposes human rights with sovereignty. ${ }^{210}$ In the words of Hedley Bull: '[c]arried to its logical

${ }^{210}$ It is also clear that the concepts of state sovereignty and human rights respectively could be dissected with the dichotomy of universalism and particularism. The development from absolute sovereignty to popular sovereignty mirrors a shift from a particularist model of power exercise to a universalist one. See further G. Noll, 'The Democratic Legitimacy of Refugee Law', 66 NJIL 429 (1997), pp. 439-51, retracing this development and performing a sublation of state sovereignty in the realisation of individual autonomy (with the benefit of hindsight, it can be stated that this sublation should have been complemented by one which subsumed individual autonomy in the concept of state sovereignty). Moreover, the confrontation of first generation rights with second and third generation rights or the opposition of negative rights with positive rights reflects the front line between particularists and universalists in human rights law. 
extreme, the doctrine of human rights and duties under international law is subversive of the whole principle that mankind should be organized as a society of sovereign states'. ${ }^{211}$

To be sure, international law not only limits, but also preserves states' sovereignty. The divide between particularism and universalism resurfaces in the UN Charter, which concurrently sets out the preservation of peace and the safeguarding of human rights among the organisation's goals enumerated in Article 1. Drawn further, the opposition of peace and human rights leads back to the opposition of a Hobbesian and a Kantian conception of international law. While the first is seized with seeking ways of mitigating a bellicose state of nature, the second seeks to create conditions for the liberation of man by natural reason. ${ }^{212}$

Does international law offer a hierarchical order between these paradigms? The goal of preserving international peace ultimately accepts states as an end in themselves and thus connects to the particularist perspective. In that respect, international law is relativist by nature, tolerating states regardless of their conduct, as long as they tolerate others by refraining from acts of aggression. Safeguarding international peace means reaffirming state sovereignty, regardless of how it is exercised internally. The individual-focused goal of safeguarding human rights may all too easy conflict with the preservation of peace. What if a state engages in genocide, which may only be halted by means of a military intervention? Fully in line with the argumentative pattern of consuming opposed paradigms, such situations have been redefined as a threat to peace, allowing the UN Security Council to pursue universalist goals under the cover of a particularist paradigm. ${ }^{213}$ One should be careful not to draw hasty conclusions from this ostensible sublation. On a pragmatic level, the

${ }^{211}$ H. Bull, The Anarcbial Society (1977, Macmillan, London), p. 146.

${ }^{212}$ An excellent opposition of the Hobbesian and Kantian perspectives on international law can be found with A. Honneth, 'Is Universalism a Moral Trap? The Presuppositions and Limits of a Politics of Human Rights', in J. Bohman and M. Lutz-Bachmann (eds), Perpetual Peace. Essays on Kant's Cosmopolitan Ideal (1997, The MIT Press, Cambridge, MA), pp. 155-78. See also C. Schmitt, Der Begriff des Politischen (1963, Berlin), p. 59, elaborating the possibility of dividing theories of the state and the political into those which assume humankind to be good and those which assume it to be evil.

${ }^{213}$ For the establishment of the Ad-hoc tribunals, the Security Council reconstructed the issue as a threat to peace, which could be alleviated by adjudicating the perpetrators of the crimes. See further D. Shraga and R. Zacklin, 'The International Criminal Tribunal for the Former Yugoslavia', 5 EJIL 360 (1994). 


\section{CHAPTER 2}

need for redefinition stems solely from the fact that the Charter offers specific procedures for the preservation of peace under Chapter VII, while it contains no procedures for protecting human rights. In Article 1 UNC, as well as in the preamble, both goals stand side by side.

If there is any instrument of constitutional character in international law, it is the UN Charter. All the more, and quite understandably, its letter can reproduce, but not sever the Gordian knot of conflicting paradigms. And there are certainly reasons for that-one being the pedigree of the underlying conflict, which we shall retrace in the subsequent section.

\subsection{Artefact versus Organism}

The contemporary universalist narrative draws a picture of a world changing towards 'the better': the Westphalian system is being transgressed, the nation state finds itself dethroned as the primordial actor of international law, transboundary communities as well as the international rule of law proliferate around the globe. ${ }^{214}$ The particularist is sceptical of all such teleological optimism, denounces it as wishful thinking, and insists on the importance of territorially organised power. ${ }^{215}$ For a particularist, the nation state is as an ultimate guarantor of some

214 The heyday of international legal optimism coincided with the post-Cold War emergence of various global governance narratives. A pertinent example is D. Held, Democracy and the Global Order. From the Modern State to Cosmopolitan Governance (1995, Polity Press, Cornwall), especially Chapter 12 on Cosmopolitan Democracy and the New World Order. From the angle of international law, a piece resounding with high-strung idealism can be found with P. Allot, 'Reconstituing Humanity-New International Law', 3 EJIL 219 (1992), calling for the formation of a 'new international society' from which statesocieties would derive their social power (para. 40.3) and a new breed of international lawyers as 'agents of the self-perfecting human spirit' (para. 41.4). - However, there is a long-standing tradition of putting the predominance, or, indeed, the survival of the nation state into question, going back to French syndicalism of the late $19^{\text {th }}$ century and Harold Laski's writings in the early decades of the $20^{\text {th }}$ century. In that sense, the statescepticism of the 1990s is but a re-staging of this topos, predictably followed by counterarguments underscoring the continuing importance and vitality of the nation-state.

${ }^{215}$ For a good discussion of approaches centering on the responsibility of sending countries and the prevention of outflows and thus perceiving refugees as an anomaly, see D. Warner, 'The Refugee State and State Protection', in F. Nicholson and P. Twomey (eds), Refugee Rights and Realities. Evolving International Concepts and Regimes (1999, Cambridge University Press, Cambridge), pp. 262-8. 
form of law and order. In all, the particularist seems to be more occupied with keeping chaos at bay than striving for a better state of affairs.

Universalist thinking rests on a history of thought stretching from enlightenment rationalism to contemporary modernism, ultimately resting on the belief that reality can be modified through the will of man. Historically, this approach has been countered by such diverse strands of thought as romanticism, positivism, system theory, and, finally, postmodernism. Within legal thinking, the repercussions of these paradigmatic crusades are manifold. Against the universalist thrust, countercurrents emerged, linking German $18^{\text {th }}$ century historicism to the scepticism of 1920s anti-liberal thought and, finally, the indeterminacy critique formulated within the Critical Legal Studies movement. ${ }^{216}$ As Tönnies has expounded, the contesters of universalism share a common belief in organically grown rather than man-made orders. ${ }^{217}$ Therefore, she regards the dispute between universalism and particularism as just another variation of the tension between organism and artefact-the question being whether the dictates of nature or the dictates of man shall prevail in the formation of reality. ${ }^{218}$

Within the discipline of international relations, the same pattern reverberates in the classical debate between idealists and realists. ${ }^{219}$ Another fault line is the opposition between essentialism and constructivism in contemporary feminist theory. ${ }^{220}$ Within moral philosophy, the couplet of utlilitarian and deontological approaches reproduces this conflict once more. It goes without saying that the named schools of thought diverge to a great extent, and cannot be solely reduced

216 The indeterminacy critique takes a prominent place both in anti-liberal thinking of the 1920 s and the Critical Legal Studies movement. See W. Scheuermann, Between the Norm and the Exception: The Frankfurt School and the Rule of Law (1994, MIT Press, London), pp. 245-8.

217 S. Tönnies, Der Dimorphismus der' Wabrheit (1992, Westdeutscher Verlag, Opladen), pp. 17-33.

${ }^{218}$ For a comprehensive overview of dimorphism in legal theory, see 'Tönnies' work, supra. The debate on voluntarism and determinism is an important issue within Critical Legal Studies. For an introduction, see M. Kelman, A Guide to Critical Legal Studies (1987, Harvard University Press, Cambridge, MA), pp. 86-113.

219 For an overview, see R. A. Crawford, Idealism and Realism in International Relations (1999, Routledge, London).

220 See e.g. E. Kingdom, 'Citizenship and Democracy: Feminist Politics of Citizenship and Radical Democratic Politics', in S. Millns and N. Whitty (eds), Feminist Perspectives on Public Law (1999, Cavendish Publishing, London), pp. 158-62. 


\section{CHAPTER 2}

to their affirmation or contestation of universalism. Moreover, as we shall see later on, there is no such thing as a purely universalist or purely particularist approach. Each of these paradigms falls apart into opposing strands, which internalise the divide between universalism and particularism. ${ }^{221}$ But there is also an argumentative interdependence between the paradigms. In order to win recognition by outsiders, particularism is usually argued with reference to universal concepts, while universalists feel compelled to particularist delimitations in order to secure the pragmatic viability of their theories. ${ }^{222}$

Within international law, this dimorphic pattern of thought is already present in the Grotian division, distinguishing natural law from manmade law, and has been exposed to a multitude of variations ever since. ${ }^{223}$ As one would expect, this divide and the dynamics caused by it also inform refugee research. ${ }^{224} \mathrm{We}$ find a limitative school, which remains largely unwilling to discuss the migrational context of flight, other than those human rights violations being its immediate cause. It advocates a strict separation of migration and extraterritorial protection, pointing at the specific legal norms governing the latter. Moreover, this strand fears

${ }^{221}$ By way of example, utilitarianism comes in a rule-focused and action-focused variety. For an example from the area of political theory, see our analysis of Frost's approach (text accompanying note 249 below).

222 See chapter 2.6 below.

223 A pertinent example is Koskenniemi's 'From Apology to Utopia', structuring international law as an oscillating movement between utopian and apologetic arguments. See Koskenniemi, 1989, p. 193, exercising the sovereignty concept through this oscillating movement. For a traditional structuring of international law along universalist and particularist fault lines, see Verdross and Simma, 1984, p. 11 et seq.

${ }^{224}$ For an excellent analysis of the interplay between positivist and non-positivist refugee research since the sixties, see B. S. Chimni, 'The Geopolitics of Refugee Studies: A View from the South', 11 Journal of Refugee Studies 350 (1998). Chimni holds that the perseverance of positivist refugee law within refugee studies led to a fragmented approach, which turned a blind eye to the political contingency of norm-creating and interpretation. On the other hand, those refugee scholars criticising the positivists opened the door to what Chimni denounces as the 'repatriation turn' in the eighties, propagating assistance and protection in the region of origin. Chimni, 1998, pp. 351-5. In a thoughtful essay, Warner has broken down refugee discourse along a slightly different fault line. To him, there are two groups: one sees the state as the major problem, the other perceives it as the major solution. While the first conceives of the refugee as 'paradigmatic in the sense of a physical representation of the dislocation of the modern condition', the second sees her as an atypical, special category of persons. Warner, 1999, pp. 253-4. 
that an expansion of research to broader political issues would dilute the specific character of refugeehood-and the privileged position the refugee enjoys over other categories of migrants. ${ }^{225}$ Typically, its proponents adhere to a paradigm based on legal positivism. The expansive school holds that flight cannot be isolated from a wider migrational and political context. Its proponents are sceptical toward a depoliticised approach based on legal positivism, and wish to complement it with elements of economic and political analysis. This analysis draws mainly on the observation of global inequality:

- the facilitated exchange of capital and goods around the globe has not been matched by a similar deregulation of migration. Seemingly out of tune with liberalisation, migration has become increasingly regulated and controlled throughout the last decades ${ }^{226}$;

- global income disparities have increased in the same vein ${ }^{227}$;

O the number of armed conflicts around the world is on the rise; and

$\bigcirc$ in the light of these factors, demographers are surprised by the relative stability of migration. ${ }^{228}$

${ }^{225}$ See, e.g., Martin's argument, presented in chapter 2.3 above.

226 'Regional trends support the view that in all parts of the developed and developing worlds, a growing number of Governments have adopted policies aimed and influencing, and, especially, lowering the immigration level. While in 1976, a majority of countries in Asia, Europe and Oceania had a policy of non-intervention towards immigration, the percentage of non-interventionist countries was down to about 15 per cent in each of these regions in 1995.' UN Department of Economic and Social Affairs, Population Division, International Migration Policies (1998, UN, New York), p. 5.

227 The gauge of global income inequality combines inequality within countries with inequality between states. Inequality is measured by the Gini coefficient, which ranges between 0 (complete equality) and 100 (complete inequality). Milanovic has shown that the global Gini coefficient has increased from 63 in 1988, to 66 in 1993. B. Milanovic, True World Income Distribution, 1988 and 1993: First Calculations, Based on Housebold Surveys Alone. World Bank Policy Research Working Paper (1999, The World Bank, Washington D C), p. 51.

228 'Despite the lack of comprehensive data on a global level, it is possible to affirm that the global number of international migrants has been growing at an increasing rate since 1965. However, given the concomitant increase in the number of distinct units (countries and territories) constituting the world and the persistence of sharp economic and demographic disparities among countries and regions, coupled with the widespread prevalence of political instability and outright conflict, the percentage of people who have left and remained outside their countries of origin is remarkably small and has been relatively stable 


\section{CHAPTER 2}

Proponents of a universalist approach wish to extend the study of refugee issues to possible causal chains leading from economic deprivation via factional conflict to persecution and flight. For such universalists, the individual quest for protection is inextricably linked to global redistribution. Their argument is that any protection claim may be the result of an unjust world order, of which the potential host state is a profiteer. ${ }^{229}$

Our crude synopsis may suffice to illustrate that the conflict between Mr. Chahal and the U.K. population is far from finding a determinate outcome through a theoretical shortcut. This overview also illustrates that neither the universalist nor the particularist strand are monolithic entitities. Being interested in refugees does not automatically make one a universalist, and preserving the nation state need not be an expression of egoistic particularism. Rather, both strands hold a number of smaller strategic and methodological conflicts, which mirror and reproduce the universalist-particularist divide within each strand.

for a long period, oscillating between 2.1 and 2.3 percent of the world's population during 1965-90.' [Emphasis added] H. Zlotnik, 'Trends of International Migration since 1965: What Existing Data Reveal', 37 International Migration 21 (1999), p. 42.

229 The following two quotes from the eighties may provide interesting illustrations of this approach.

'Politische Repressionen insbesondere in den Ländern der Dritten Welt werden vorrangig duch ein das westliche Interesse befördernde [sic] Weltwirtschaftssystem verursacht. [...] Die öffentliche Stigmatisierung der Flüchtlinge aus der Dritten Welt als sogenannte Scheinasylanten ist Teil des Verdrängungsprozesses einer Industriegesellschaft hinsichtlich der sozialen und politischen Folgen des Wirtschaftssystems im Süden.' ['Political repressions, especially in the countries of the third world, are primarily caused by a global economic system furthering Western interests. [...] The public stigmatisation of refugees from the third world are part of a suppression process of an industrial society with regard to the social and political consequences of the economic system in the South.' Translation by this author.] R. Marx, Eine menschenrechtliche Begründung des Asylrechts (1984, Nomos Verlagsgesellschaft, Baden-Baden), pp. 227-8.

'The moral obligation of the North to share the global asylum burden rests on its enormous resource capabilities relative to those of the South, and on the transnational dynamics of social conflict in the contemporary world, which at least to some degree makes the North corresponsible for the upheavals in the South.' A. R. Zolberg, A. Suhrke and S. Aguayo, Escape from Violence. Conflict and the Refugee Crisis in the Developing World (1989, Oxford University Press, Oxford), p. 279. 


\subsection{Meandering Arguments}

Dividing positions on access to extraterritorial protection into a universalist and a particularist strand does, of course, injustice to the complexity of thought behind them. While we are unable to depict an impressively rich and refined debate here ${ }^{230}$, we would like to present a number of intermediary positions, showing-that universalists perforce integrate particularist elements into their arguments, and vice versa. This does not mean, though, that universalism and particularism end up in about the same result. Quite the contrary: both approaches dictate a certain procedure to be followed when negotiating access to the protection of communities. This necessarily has repercussions on the precise location of boundaries and the formulation of limits.

Let us first look at Bruce Ackerman, who addressed fundamental questions of membership in his work 'Social Justice in the Liberal State'. The underlying idea of his theory is that, in discussions on the just distribution of various goods, the challenged party cannot respond by asserting the moral inferiority of the challenging party, when faced with the question of legitimacy. ${ }^{231}$ This is a specification of the principle of equality, identified earlier as the pivotal element in the universalist approach. Ackerman develops his theory along a dialogic form of reasoning, and elaborates very aptly that, in practice, the enjoyment of goods is made contingent on membership in a community. In that sense, membership is a good prior to all other goods. However, different from particularists, he does not stop there, but subjugates the distribution of membership to the same justificatory tests as applied to the distribution of other goods. This leads him to claim that 'the only reason for restricting immigration is to protect the ongoing process of liberal conversation

${ }^{230}$ A carefully compiled and instructive survey of the debate in political theory can be found with A. Somek, 'Einwanderung und soziale Gerechtigkeit', in C. Chwaszcza and W. Kersting (eds), Politische Pbilosopbie der internationalen Beziebungen (1998, Suhrkamp, Frankfurt am Main), structuring it along the divide between liberals and communitarians. For an interesting, although at times polemical, overview see C. Joppke, 'Immigration Challenges the Nation-State', in C. Joppke (ed.), Challenge to the Nation-State (1998, OUP, Oxford), using the fault-line of globalists and non-globalists (one should disregard his misguided perception of human rights law as 'soft law').

231 B. Ackerman, Social Justice in the Liberal State (1980, Yale University Press, New Haven), p. 93. 


\section{CHAPTER 2}

itself'. ${ }^{232}$ As an example, Ackerman refers to situations where 'the presence of so many alien newcomers will generate such anxiety in the native population that it will prove impossible to stop a fascist group from seizing political power to assure native control over the immigrant underclass'. ${ }^{233}$ We note the difference with respect to the particularist position: it is one thing to protect a specific community from a migratory influx, it is quite another to vouchsafe the 'ongoing process of liberal conversation'. If anything, the latter goal entails a greater argumentative burden to justify exclusion. Moreover, while the particularist is seized with protecting the resources-material or political-of the community in which membership is sought, Ackerman is concerned with preserving a political resource-the natives' consent to maintaining a liberal political order. This reproduces a Rawlsian approach, giving precedence to the enjoyment of fundamental rights over the enjoyment of material goods. ${ }^{234}$

Another good illustration is provided by Joseph Carens' critique of Walzer. In particular, Carens takes issue with Walzer's assertion of states' freedom to determine inclusion and exclusion. ${ }^{235}$ Carens then observes that we let the right to free migration within states prevail over the seclusionist wishes of cities and provinces, although migration has detrimental economic consequences to them, and might even change the character of these communities. ${ }^{236}$ 'If freedom of movement within the state is so important that it overrides the claims of local political communities, on what grounds can we restrict freedom of movement across states?' asks Carens, suggesting that such restriction 'requires as stronger case for the moral distinctiveness of the nation-state as a form of community than Walzer's discussion of neighbourhoods provides' ${ }^{237}$

Secondly, and probably more decisively, Carens unravels that Walzer's defence of particularism draws on universalist language and rationality, and that communitarianism is dependent on a liberalist mode of thinking:

\footnotetext{
232 Ackerman, 1980, p. 95. Emphasis in the original.

233 Ackerman, 1980, p. 93.

${ }^{234}$ Somek, 1998, p. 415.

${ }^{235}$ Of lesser importance for our purposes, Carens also criticises Walzer's comparison between states and private clubs for ignoring the divide between public and private spheres, which Walzer draws on in other parts of his theory. J. H. Carens, 'Aliens and Citizens: The Case for Open Borders', IL Review of Politics (1987), pp. 266-8.

236 Carens, 1987, p. 267.

${ }^{237}$ Carens, 1987, p. 267. Emphasis in the original.
} 
Any approach like Walzer's that seeks its ground in the tradition and culture of our community must confront, as a methodological paradox, the fact that liberalism is a central part of our culture. The enormous intellectual popularity of Rawls and Nozick and the enduring influence of utilitarianism attest to their ability to communicate contemporary understandings and shared meanings in a language that has legitimacy and power in our culture. ${ }^{238}$

Following Carens, ' $[\mathrm{t}] \mathrm{o}$ take our community as a starting point is to take a community that expresses its moral views in terms of universal principles'. ${ }^{239}$ Subsequently, Carens submits that Walzer's argument against states' right to expel certain residents or to restrict emigration is framed in universal terms, applying not only to our particular state, but to all states. With this universality of rules comes a universality of individuals' equal moral worth. ${ }^{240}$ And Walzer's stipulation of a state right to exclude would violate this basic liberal principle, ingrained in our community and expressed in universal terms.

While basing his case for open borders on a liberal tradition represented by Rawls, Nozick and utilitarianism, Carens is careful not to strip membership qua citizenship of all distinctive meaning:

To say that membership is open to all who wish to join is not to say that there is no distinction between members and nonmembers [sic]. Those who choose to cooperate together in the state have special rights and obligations not shared by noncitizens. Respecting the particular choices and commitments that individuals make flows naturally from a commitment to the idea of equal moral worth. [...] What is not readily compatible with the idea of equal moral worth is the exclusion of those who want to join. If people want to sign the social contract, they should be permitted to do so. $^{241}$

Carens then asserts that our fears of immigration as threatening the distinctive character of our community or its resource base assume that many people would move if they only could. He counters this assumption

\footnotetext{
238 Carens, 1987, pp. 268-9. Emphasis in the original.

239 Carens, 1987, p. 269. Emphasis in the original.

240 Carens, 1987, pp. 269-70.

241 Carens, 1987, p. 270 . Emphasis in the original.
} 


\section{CHAPTER 2}

by claiming that, at the end of the day, people only move if life is very difficult where they are. Thus, he concludes, when weighing the interests of migrants against those of the host community, the case of exclusion 'will rarely triumph'. ${ }^{242}$

Notwithstanding Carens' primary interest in equality, this goes to show that he is principally prepared to set limits for access to the host community. So is Ackerman, as we noted earlier. The limits of access are to be assessed by weighing the interests of members against those of nonmembers. So far, universalists and particularists use the same argumentative techniques. But the approaches differ in what factors they admit to the weighing process and the weight they attach to these factors. Quite clearly, particularists grant membership in a community-e.g. citizenship, nationality or ethnicity-a special weight.

Let us briefly consider an example of how a particularistcommunitarian approach is put to work by a refugee lawyer. David Martin is a prime exponent of that profession in the U.S. and when he makes a case for a restrictive legal entitlement to asylum, he certainly does so in a thoughtful, balanced manner. Here is his argument. An 'overly expansive' legal entitlement to asylum should be avoided, because it drains domestic political support not only for asylum itself, but also for other, related political decisions (such as the granting of temporary protection, or the creation of safe havens). ${ }^{243}$ Thus, Martin's argument unfolds from a primacy of the host state's electorate. This may be considered realistic, but for us, the communitarian core of this argument is probably more interesting. However, most intriguingly, Martin does not stop with the preferences of host countries:

Refugee law, taken to extremes, ironically can demean those it means to benefit. Its focus is solely on haven, on sheltering people who fear their governments-as though governments never had anything to fear from the people, as though the act of leaving in search of individual relief would have no impact on the ongoing struggle for community reform. With its "exilic bias" (a telling phrase used by Professor Hathaway), ambitious refugee law tends to treat people as history's pawns, never its players: as objects,

242 Carens, 1987, p. 270.

243 Martin, 1991, p. 37. 
always on the receiving end of home government action, not as subjects capable of acting in their own right.

A narrower political standard, of the kind I advocate here, respects this capacity in those persons. [...] Such an approach also husbands the limited political reserves that keep asylum vital in the haven countries for those who are in greatest jeopardy. ${ }^{244}$

Whatever one may think of its intrinsic merit, Martin's suggestion is a successful exploration of the structural power inherent in the particularist position, doing away with its egoistic overtones. Restriction of access to extraterritorial protection is necessary not only to preserve the interests of potential host societies, but also those of the refugees themselves. Rhetorically, there is some appeal to it: by focusing on the provision of haven only, we reify refugees. The underlying communitarian logic may read like this: haven is a false hope, because it juxtaposes the individual in flight to the wrong society. In the long term, the true potential of the individual can only be realised in her own society-the society she fled from.

Nonetheless, there are important flaws to Martin's argument. To deny haven to outsiders for the benefit of a community is to reify outsiders. And, if we are eager to reframe the refugee as history's agent, rather than its object, how can we disrespect her decision for flight? Why should historical agency, including the right to transform communities, be confined to one's own community? Just as Carens questioned Walzer, we are compelled to question Martin: what are the compelling reasons for confining agency to the citizen, and barring the refugee from it? This brings us back to the preferential treatment of membership in the weighing process described earlier. Such preference is clearly incompatible with the universalist's insistence on equality. But beyond that, how can this privileged position be justified within a particularist approach?

An answer may be sought with David Miller, who tried to argue for nationality as a privileged form of membership from a particularist perspective. At the outset, he underscores that national boundaries are not congruent with state boundaries, and identifies nationality as

244 Martin, 1991, p. 46. 


\section{CHAPTER 2}

essentially a subjective phenomenon, constituted by the shared beliefs of a set of people: a belief that each belongs together with the rest; that this association is neither transitory nor merely instrumental but stems from a long history of living together which (it is hoped and expected) will continue into the future; that the community is marked off from other communities by its members' distinctive characteristics; and that each member recognizes a loyalty to the community, expressed in a willingness to sacrifice personal gain to advance its interests. ${ }^{245}$

To justify the trump status of nationality, Miller questions the rationality concept underlying universalist positions, and opposes it with a particularist counterpart:

Most theories of a universalist type do [...] make room for
individuals' particular duties, responsibilities and rights - the duties
of parents, colleagues, and so on-but these are never regarded as
fundamental commitments. The moral self is defined by its rational
capacities, so only general principles can have this basic status;
other commitments are contingent and subject to revision if, for
example, new facts come to light which demand this. In contrast,
consider a second view of ethical agency in which the subject is
seen as already deeply embedded in social relationships. Here the
subject is partly defined by its relationships and the various rights,
obligations, and so forth that go along with these, so these
commitments themselves form a basic element of personality. On
this view, the agent can still aspire to rationality, but the rationality
[...] consists in the capacity to reflect on existing commitments,
jettisoning some and reaffirming others, depending on how they
stand up to scrutiny. ${ }^{246}$

This conception of rationality entails a problem, however, which Miller unsuccessfully attempts to resolve. If the degree of human 'embeddedness' in communities is a trump criterion for establishing obligations towards others, how does a particularist tackle loyalty conflicts, by which the individual is torn between competing communities? If the choice is to be loyal towards, say, an ethnic community and a national community (a conflict actually canvassed by Miller), a particularist would be forced to

\footnotetext{
245 Miller, 1988, p. 648.

246 Miller, 1988, pp. 649-50.
} 
abandon the latter for the former. Miller merely argues for harmonizing ethnic and national obligations, and makes an argument for 'having national allegiances that promise to protect your ethnicities [footnote omitted, GN]'. ${ }^{247}$ Basically, this reproduces the argument of the universalist who pushes for the primacy of human rights over membership: one day, the state may be unable or unwilling to protect you. Then, human rights are the only residual protection. Miller's argument is analogous: ethnicity may not be able to secure political autonomy, while nationality does. ${ }^{248}$ The smaller unit will fail to protect you, and therefore, it is better to grant primacy to the larger unit-be it in the form of human rights or nationality. So, for the particularist, the question of drawing the line poses itself somewhat differently. She has to choose between competing forms of embeddedness: family, friends, neighbourhoods, ethnicities, nationalities. In doing so, she has to take a perspective external to the compared embeddednesses. With the benefit of Carens' analysis, we may conclude why drawing this line is so difficult for particularists: after all, 'embeddedness' is a criterion grounded on the universalist rationality of a neutral observer's perspective.

Mervyn Frost offers an interesting example of a particularist approach with a strong universalist twist. His 'constitutive theory of individuality' is a communitarian one, stressing that we are constituted as ethical beings within communities, and that only within these, we can sensibly conduct ethical discussion. ${ }^{249}$ Nonetheless, he does not identify a single community as constitutive, but resorts to a hierarchy of institutions whose boundaries do not coincide. 'In constitutive theory, migrants are not portrayed as outsiders, but as insiders within the hierarchy of our wider ethical community, global civil society. ${ }^{250}$ This brings him to a conclusion reminiscent of universalist positions. Frost recognises the presumption that people have a right to freedom of movement and that '[d]emocratic states may only limit movement when they have good reason to believe

${ }^{247}$ Miller, 1988, p. 659. Although less radically formulated, the element of sacrifice is parallel to that of Carl Schmitt's delimitation of a political community, turning on an individual's willingness to kill and to die for that community. See Schmitt, 1963, p. 46, and the discussion in chapter 13.1.2 below.

${ }^{248}$ In this argument, Miller disregards his initial distinction between nation and state. Miller, 1988, pp. 422 and 453.

${ }^{249}$ M. Frost, 'Migrants, Civil Society and Sovereign States: Investigating an Ethical Hierarchy', XLVI Political Studies (1998), p. 878.

250 Frost, 1998, p. 879. 


\section{CHAPTER 2}

that the migrant civilians are seeking to "tap in" to the services which the citizens have established exclusively for themselves'. ${ }^{251}$ If, however, migrants can show that they will not become free riders, they may not be excluded. It is strikingly quixotic that the communitarian axiom is complemented with an economistic criterion for determining inclusion and exclusion. The contradiction inherent in being 'embedded' into the largest unit conceivable-global civil society-annihilates Frost's credibility as a communitarian. And his economistic delimitation criterion is too anti-egalitarian to convince universalists. While necessary, straddling over two paradigms also has its risks.

In this chapter, our ambition was to profile the dynamics underlying the conflict between freedom and equality in the law of extraterritorial protection, and to reveal some of the typical manoeuvres performed by universalist and particularist actors. We have done that for the realm of political theory, illustrating how the dichotomy between universalism and particularism refines the question of delimitation by demarcating argumentative paths to be followed. It has also emerged that particularism cannot be theoretically defended without universalist arguments, and that universalism is in need of particularist delimitations to sustain its pragmatic dimension. In the legal analysis, we shall see this couplet of mutual affirmation reappear. ${ }^{252}$

Now, to clear our thoughts further on the interrelationship between the two approaches, we must leave the realm of abstraction and descend to the nitty-gritty of specific norms and everyday legal conflict. This brings us back to the initial questions. What norms govern the attribution of extraterritorial protection? How are they interpreted? Provided there is a balance between universalism and particularism implied in international law, it should emerge here.

${ }^{251}$ Frost, 1998, p. 885. Emphasis in the original.

${ }^{252}$ See chapter 10.1.1.1 below, analysing the reasoning of the ECtHR on the issue of extraterritorial protection as an amalgam of universalist and particularist arguments. 